\title{
KINERJA ORGANISASI PADA KANTOR BADAN PENANGGULANGAN BENCANA DAERAH KOTA PALU
}

\section{ORGANIZATIONAL PERFORMANCE OF THE REGIONAL DISASTER MANAGEMENT AGANCY OFFICE IN THE CITY OF PALU}

\author{
Kemala Novriyanti, Muh.Irfan Mufti, Shadiq, Muhammad Ahsan Samad \\ Program Studi Administrasi Publik, Fakultas Ilmu Sosial dan Ilmu Politik \\ Universitas Tadulako, Palu \\ J1. Soekarno Hatta No.KM. 9, Tondo, Mantikulore, Kota Palu \\ E-mail : kemalanovriyanti97@gmail.com \\ Rudi Salam \\ Pendidikan Administrasi Perkantoran, Universitas Negeri Makassar \\ Jl. A. P. Pettarani, Tidung, Kota Makassar
}

Naskah diterima tanggal 4 Mei 2020. Naskah direvisi tanggal 29 Juni 2020.

Naskah disetujui tanggal 7 Juli 2020

\begin{abstract}
Abstrak
Tujuan penelitian ini dilakukan untuk mengetahui Kinerja Organisasi pada Kantor Badan Penanggulangan Bencana Daerah kota Palu. Tipe penelitian yang digunakan deskriktif kualitatif yaitu memberikan gambaran dan penjelasan lebih rinci dari variabel yang dilakukan melalui teknik penelitian kepustakaan serta penelitian lapangan yang terdiri dari observasi secara langsung ke objek penelitian, wawancara secara langsung kepada informan, dan dokumentasi. Informan dalam penelitian ini ditentukan secara purpossive berjumlah 7 (Tujuh) Orang. Penelitian ini menggunakan Teori Agus Dwiyanto (2015) dimana ada 5 (Lima) Indikator untuk mengukur kinerja organisasi yang meliputi Produktivitas, Kualitas Layanan, Responsivitas, Responsibilitas, Akuntabilitas. Dari hasil penelitian menunjukan bahwa produktifitas pada kantor Badan Penanggulangan Bencana Daerah kota Palu belum berjalan dengan baik, dalam hal ini dilihat dari aspek tingkat kedisiplinan pegawai perlu ditingkatkan lagi, sumber daya manusia yang kurang memadai baik dari segi jumlah maupun kemampuan, kemudian responsivitas pada kantor Badan Penanggulangan Bencana Daerah kota Palu masih perlu diperhatikan terkait dari beberapa program yang dijalankan belum sesuai dengan harapan masyarakat.
\end{abstract}

Kata Kunci: Efektifitas, Pelayanan Publik, SOP

\begin{abstract}
The purpose of this study was to determine the Organizational Performance of the Regional Disaster Management Agency Office in the city of Palu. The type of research used qualitative descriptive is to provide a more detailed description and explanation of the variables carried out through library research techniques and field research consisting of direct observation to the object of research, interviews directly to the informants, and documentation. Informants in this study were purposively determined to be 7 (Seven) people. This study uses the theory of Agus Dwiyanto (2015) where there are 5 (Five) Indicators to measure organizational performance which include Productivity, Service Quality, Responsiveness, Responsibility, Accountability. From the results of the study showed that productivity at the Regional Disaster Management Agency Office in the city of Palu has not gone well, in this case seen from the aspect of the level of discipline of employees needs to be improved again, inadequate Human Resources both in terms of quantity and ability, then responsiveness to the agency office Regional Disaster Management in the city of Palu still needs to be considered related to the number of programs that
\end{abstract}


have been implemented that have not been in accordance with the expectations of the community.

Keywords: Performance, Organization, Productivity, Service Quality, Responsiveness.

\section{PENDAHULUAN}

\section{Latar Belakang}

Berdasarkan Undang-Undang No.24 tahun 2007 tentang penanggulangan bencana, Pemerintah Daerah diwajibkan untuk menyelenggarakan kegiatan penanggulangan bencana di daerahnya. Kegiatan tersebut meliputi pemenuhan hak masyarakat yang terkena bencana, perlindungan dari dampak bencana, peningkatan kapasitas masyarakat untuk mengurangi resiko bencana, dan pembangunan fisik yang ramah bencana. Oleh karena itu, pada setiap tahun sebagian Anggaran Pendapatan dan Belanja Daerah (APBD) wajib dialokasikan untuk kegiatan penanggulangan bencana. Karena itu pula, Pemerintah Daerah memiliki hak untuk menetapkan kebijakan penanggulangan bencana yang selaras dengan kebijakan pembangunan daerah dengan memasukan unsur-unsur potensi alam dan teknologi. Pada umumnya, resiko bencana alam meliputi bencana akibat faktor geologi (gempa bumi, tsunami,dan likuifaksi), bencana akibat hydometeology (banjir, tanah longsor, kekeringan, dan angin topan), bencana akibat faktor biologi (wabah penyakit manusia, penyakit tanaman/ternak, hama tanaman) serta kegagalan teknologi (kecelakaan industri, kecelakaan transportasi, pencemaran bahan kimia). Bencana akibat ulah manusia terkait dengan konflik akibat perebutan sumber daya yang terbatas, alasan ideologi, religious, dan politik (Nurjanah:2012).

Dalam merespon upaya penanggulangan bencana Pemerintah memerlukan dukungan dari organisasi organisasi pemberi bantuan, seperti yang dikemukakan oleh Helsloot dan Ruitenberg (2004), bahwa pemerintah saat di mana bencana terjadi tidak mungkin mampu untuk merespon bencana secara sendirian. Berbagai kerja sama antar pemangku kepentingan dalam penyelenggaraan pemerintahan juga dilakukan sebagai suatu usaha dalam respon langkah pemerintah dalam kegiatan penanganan masalah publik. Kebutuhan akan partner dan asistensi ini menunjukkan adanya urgensi akan tata kelola yang baik yang terpadu dengan pendekatan collaborative governance (Daswati, Samad, \& Wekke, 2019)

Dalam proses penanggulangan bencana yang dilakukan melalui pencegahan, mitigasi, kesiapsiagaan, tanggap darurat, serta rehabilitasi dan rekonstruksi yang mengacu pada Peraturan Daerah (PERDA) Kota Palu Nomor 2 Tahun 2009 Tentang Pembentukan Organisasi dan Tata Kerja Badan Penanggulangan Bencana Daerah dan Peraturan Daerah Kota Palu No. 05 Tahun 2011 tentang Penyelenggaraan Penanggulangan Bencana, belum sepenuhnya berjalan dengan baik pada kantor Badan Penanggulangan Bencana Daerah (BPBD) kota Palu, hal ini dalam kinerja organisasi.

Membahas tentang kinerja, terlebih dauhulu perlu mereview kembali pemahaman tentang arti dari kinerja tersebut, yang mana pada dasarnya kinerja terbagi menjadi dua yaitu kinerja individu dan kinera organisasi. Kinerja seorang individu merupakan hasil suatu kerja yang dibebankan kepadanya dalam suatu organisasi sedangkan kinerja organisasi adalah totalitas hasil kerja yang dicapai suatu organisasi. Jadi dapat dikatakan bahwa kinerja merupakan suatu wujud tingkat loyalitas kerja seorang maupun beberapa orang dalam organisasi untuk memenuhi tujuan dari organisasi itu sendiri (Moeheriono:2014).

Guna meningkatkan kinerja pada kantor Badan Penanggulangan Bencana Daerah kota Palu. Tentunya pihak kantor Badan Penanggulangan Bencana Daerah kota Palu dituntut untuk mengoptimalkan peran dan fungsinya. Adapun fungsi dari 
BPBD kota Palu pada saat tidak terjadi bencana yaitu dimana mereka menjadi fungsi koordinasi, pada saat terjadi bencana mereka mengganti fungsi menjadi fungsi komando, dan pada fase pasca terjadi bencana fungsi mereka kembali menjadi fungsi koordinasi. Selain peran dan fungsi juga diperlukan faktor-faktor lain seperti sarana dan prasarana, kinerja aparaturnya, serta kebijakan yang dibuat oleh kantor Badan Penanggulangan Bencana Daerah kota Palu tersebut.

Namun di era sekarang ini kinerja Badan Penanggulangan Bencana Daerah kota Palu sering kali mendapat sorotan tajam dari kalangan masyarakat. Hal ini berdasarkan keluhan-keluhan yang didapatkan dari proses wawancara adapun salah satunya menurut ibu Mutmainah dimana beliau mengatakan kualitas pelayanan yang diberikan oleh kantor BPBD kota Palu belum maksimal karena beliau sebagai masyarakat belum pernah sekalipun mendapatkan sosialisasi mengenai pengetahuan tentang ilmu penanggulangan bencana sehingga pengetahuan beliau masih sangat minim dan menjadikannya tidak siap dalam menghadapi bencana. Ini menandakan bahwa dalam proses output kinerja kantor Badan Penanggulangan Bencana Daerah kota Palu belum sepenuhnya memenuhi kebutuhan masyarakat. Oleh karena itu ini menjadi hal yang menarik bagi peneliti untuk meneliti terkait kinerja yang ada pada kantor Badan Penanggulangan Bencana Daerah kota Palu tersebut. Mengingat bahwa kantor BPBD adalah tombak dalam proses penanggulangan bencana.

\section{Rumusan Masalah}

Berdasarkan uraian latar belakang yang diuraikan diatas, maka yang menjadi rumusan masalah penilitian adalah Bagaimana kinerja kantor Badan Penanggulangan Bencana Daerah di Kota Palu?

\section{Kegunaan Penelitian}

Berkaitan dengan tujuan penelitian di atas, maka hasil penelitian diharapkan dapat digunakan sebagai berikut, Secara
Teoritik (Keilmuan) sebagai bahan kajian akademis bagi diri penulis yakni sebagai wahana pengembangan ilmu administrasi negara khususnya dibidang kinerja dan sebagai bagian dari penempatan diri dalam upaya memantapkan wawasan dan kemampuan akademik sebagai calon sarjana ilmu sosial. Secara praktis (guna laksana) dapat dijadikan bahan acuan untuk meningkatkan kinerja yang lebih baik bagi Komisi Pemilihan Umum (KPU) Kota Palu.

\section{TINJAUAN PUSTAKA}

\section{Konsep Kinerja}

Konsep kinerja pada dasarnya merupakan perubahan atau pergeseran paradigma dari konsep produktivitas. Pada awalnya, orang sering kali menggunakan isitilah produktivitas untuk menyatakan kemampuan seseorang atau organisasi dalam mencapai tujuan atau sasaran tertentu (Sudarmanto:2014). Paradigma produktivitas yang baru adalah paradigma kinerja secara aktual yang menuntut pengukuran secara aktual keseluruhan kinerja organisasi, tidak hanya efisiensi atau dimensi fisik, tetapi juga dimensi non fisik (intangible). Ada beberapa yang menjelaskan istilah kinerja merupakan terjemahan dari performance yang sering diartikan oleh para cendikiawan sebagai "penampilan", "unjuk kerja", atau " prestasi”" (Keban:2004).

Sedangkan Suyadi Prawirosentono mendefinisikan kinerja sebagai performance, yaitu hasil kerja yang dapat dicapai oleh seseorang atau sekelompok orang dalam suatu organisasi, sesuai dengan wewenang dan tanggungjawab masing-masing, dalam rangka upaya mencapai tujuan organisasi bersangkutan secara ilegal, tidak melanggar hukum dan sesuai dengan moral dan etika (Wibowo:2009). Definisi kinerja organisasi yang dikemukakan oleh Bastian dalam Hessel Nogi sebagai gambaran mengenai tingkat pencapaian pelaksanaan tugas dalam suatu organisasi, dalam mewujudkan sasaran, tujuan, misi, dan visi organisasi tersebut (Nawawi:2013).

Dari beberapa penjelasan definisi 
diatas, dapat ditarik suatu kesimpulan bahwa kinerja organisasi merupakan gambaran mengenai hasil kerja organisasi dalam mencapai tujuan yang tentu saja akan dipengaruhi oleh sumber daya yang dimiliki oleh organisasi tersebut. Sumber daya yang dimaksud dapat berupa fisik seperti sumber daya manusia maupun non fisik seperti peraturan, informasi, dan kebijakan, maka untuk lebih memahami mengenai faktor-faktor yang mampu mempengaruhi sebuah kinerja organisasi. Konsep kinerja organisasi juga menggambarkan bahwa setiap organisasi publik memberikan pelayanan kepada masyarakat dan dapat dilakukan pengukuran kinerjanya dengan menggunakan indikator-indikator kinerja melalui enam aspek yaitu produktifitas, kualitas layanan,responsifitas, responsibilitas, dan akuntabilitas (Dwiyanto, 2006).

\section{BADAN PENANGGULANGAN BENCANA DAERAH KOTA PALU}

Pembukaan Undang-Undang Dasar 1945, mengamanatkan bahwa Negara Republik Indonesia berkewajiban melindungi segenap bangsa Indonesia dan seluruh tumpah darah Indonesia. Dalam hal perlindungan terhadap kehidupan dan penghidupan termasuk perlindungan atas bencana dalam rangka mewujudkan kesejahteraan umum yang berlandaskan Pancasila telah dituangkan dalam UndangUndang Nomor 24 Tahun 2007 Tentang Penanggulangan Bencana.

Dalam Pasal 18 ayat (1) UndangUndang Nomor 24 Tahun 2007 Tentang Penanggulangan Bencana disebutkan bahwa : Pemerintah Daerah sebagaimana dimaksud dalam Pasal 5 membentuk Badan Penanggulangan Bencana Daerah. Sebagai Pedoman Pembentukan Organisasi Badan Penanggulangan Bencana Daerah, maka Pemerintah Republik Indonesia melalui Menteri Dalam Negeri menetapkan Peraturan Menteri Dalam Negeri Nomor 46 Tahun 2008 Tentang Pedoman Organisasi dan Tata Kerja Badan Penanggulangan Bencana Daerah. serta $\begin{gathered}\text { Berdasarkan ketentuan tersebut, } \\ \text { mengacu kepada Peraturan }\end{gathered}$ Pemerintah Nomor 41 Tahun 2007 tentang Organisasi Perangkat daerah, maka Pemerintah Daerah Kota Palu melalui Walikota Palu dengan persetujuan bersama Dewan Perwakilan Rakyat Daerah Kota Palu menetapkan Peraturan Daerah Kota Palu Nomor 2 Tahun 2009 Tentang Organisasi dan Tata Kerja Badan Penanggulangan Bencana Daerah Kota Palu. Undang-Undang Nomor 24 Tahun 2007 tentang Penanggulangan Bencana dimana didalam ketentuan umumnya disebutkan bahwa, penyelenggaraan penanggulangan bencana adalah serangkaian upaya yang meliputi penetapan kebijakan pembangunan yang berisiko timbulnya bencana, kegiatan pencegahan bencana, tanggap darurat, serta rehabilitasi dan rekonstruksi.

\section{METODE PENELITIAN}

Jenis penelitian yang digunakan dalam penelitian ini adalah deskriktif kualitatif. Pengertian penelitian deskriptif adalah menjelaskan secara rinci dan sistematis terkait Penanggulangan bencana. Sumber Data yang akan digunakan terbagi menjadi data primer dan data sekunder yang berupa dokumen, arsip, laporan, evaluasi, dan buku ilmiah.

Pengumpulan data dilakukan melalui metode observasi dan wawancara yang dilakukan di lapangan. Data ini juga dilengkapi dengan dokumentasi peristiwa untuk menambahkan informasi yang dibutuhkan. Adapun yang menjadi informan dalam penelitian ini yaitu, Kepala Badan Penanggulangan Bencana Daerah kota Palu, Sekretaris BPBD, Kasi Kesiapsiagaan Bencana, Kabid Kedaruratan dan Logistik BPBD kota Palu, serta Masyarakat. Para informan dipilih karena dianggap mampu memberikan informasi yang dibutuhkan penulis dalam melengkapi hasil penelitian ini.

Proses analisis data dilakukan dengan sistem Kondensasi Data (Data Condensation) dengan menyeleksi dan menyederhanakan temuan-temuan dari berbagai sumber untuk kemudian disajikan 
dengan sedemikian rupa (Data Display) sehingga bisa ditarik sebuah kesimpulan untuk menjawab rumusan penelitian (Conclusion Drawwing) yang telah dijabarkan sebelumnya.

\section{HASIL DAN PEMBAHASAN}

\section{Kinerja Organisasi pada Kantor Badan Penanggulangan Bencana Daerah kota Palu}

Penilaian kinerja merupakan suatu kegiatan yang sangat penting karena dapat digunakan sebagai ukuran keberhasilan suatu organisasi dalam mencapai misinya.Dengan melakukan penilaian terhadap kinerja maka upaya untuk memperbaiki kinerja bisa dilakukan secara lebih terarah dan sistematis. Kajian tentang kinerja kantor Badan Penanggulangan Becana Daerah kota Palu dengan peran yang diembannya memiliki nilai yang strategis, sehingga informasi tentang kinerja organisasi ini menjadi penting untuk diketahui. Untuk melakukan penelitian terhadap kinerja suatu organisasi, maka diperlukan indikator baik pada tataran ini indikator menggambarkan tingkat pencapaian atau tujuan yang telah ditetapkan baik dalam konteks perencanaan, pelaksanaan, maupun setelah kegiatan selesai.

\section{Produktivitas}

Produktivitas tidak hanya mengukur tingkat efisiensi, tetapi juga efektifitas pelayanan. Produktifitas pada umumnya dipahami sebagai rasio antara input dengan output. Konsep produktifitas dirasa terlalu sempit dan kemudian General Accounting Office (GAO) mencoba mengembangkan satu ukuran produktifitas yang lebih luas dengan memasukan seberapa besar pelayanan publik itu memiliki hasil yang diharapkan sebagai salah satu indikator kinerja yang penting. Produktivitas sangat penting dalam mengukur kinerja organisasi sebab produktivitas dalam hal ini tidak hanya mengukur tingkat efisiensi tetapi juga menyangkut aktifitas dalam pelayanan kepada masyarakat (Dwiyanto:2006).
Tingkat pencapaian produktifitas di Kantor Badan Penanggulangan Bencana Daerah kota Palu masih belum berjalan dengan maksimal, karena masih banyaknya hambatan-hambatan seperti pelayanan yang diberikan kepada masyarakat belum efektif dan efisien, sumber daya manusia yang belum memadai, sarana dan prasarana yang masih kurang, serta ketersediaan dana yang minim. Pencapaian produktifitas yang berjalan dengan baik, tentunya merupakan harapan bagi semua organisasi baik itu organisasi pemerintah maupun organisasi swasta. Untuk mencapai produktifitas yang maksimal tentunya tidak terlepas dari beberapa faktor pendukung baik itu faktor internal maupun eksternal.

\section{Kualitas Layanan}

Isu mengenai kualitas layanan cenderung menjadi semakin penting dalam menjelaskan kinerja organisasi publik. Banyak pandangan negatif yang terbentuk mengenai organisasi publik muncul karena ketidakpuasan masyarakat terhadap kualitas layanan yang diterima dari organisasi publik. Dengan demikian, kepuasan masyarakat terhadap layanan dapat dijadikan indikator kinerja organisasi publik. Dengan demikian, kepuasan masyarakat terhadap layanan dapat dijadikan indikator kinerja organisasi publik. Keuntungan utama menggunakan kepuasan masyarakat sebagai indikator kinerja adalah informasi mengenai kepuasan masyarakat sering kali tersedia muda dan murah.

Informasi mengenai kepuasan terhadap kualitas pelayanan sering kali dapat diperoleh dari media massa atau diskusi publik. Akibat akses informasi mengenai kepuasan masyarakat terhadap kualitas layanan relatif sangat tinggi, maka bisa menjadi suatu ukuran kinerja organisasi publik yang mudah dan murah dipergunakan. Kepuasan bisa menjadi parameter kinerja organisasi publik (Dwiyanto:2006). Kualitas layanan di kantor Badan Penanggulangan Bencana Daerah kota Palu saat ini belum cukup baik karena dalam proses pemberian pelayanannya masih mengalami banyak 
hambatan. Seperti kurangnya saranan dan prasarana sehingga sering kali mempengaruhi kualitas layanan yang diberikan.

\section{Responsivitas}

Responsivitas adalah kemampuan organisasi untuk mengenali kebutuhan masyarakat, menyusun agenda dan prioritas pelayanan, mengembangkan program-program pelayanan publik sesuai dengan kebutuhan dan aspirasi masyarakat. Secara singkat responsivitas disini menunjuk pada keselarasan antara program dan kegiatan pelayanan dan kebutuhan dan aspirasi masyarakat. Responsivitas dimasukan sebagai salah satu indikator kinerja karena responsivitas secara langsung menggambarkan kemampuan organisasi publik dalam menjalankan misi dan tujuannya, terutama untuk memenuhi kebutuhan masyarakat. Responsivitas yang rendah ditujukan dengan ketidaklarasan antara pelayanan dengan kebutuhan masyarakat. Hal tersebut jelas menunjukan kegagalan organisasi dalam mewujudkan misi dan tujuan organisasi publik. Organisasi yang memiliki responsivitas rendah dengan sendirinya memiliki kinerja yang kurang maksimal (Dwiyanto:2006).

Responsivitas di kantor Badan Penanggulangan Bencana Daerah kota Palu belum berjalan dengan baik, karena masih ada beberapa program yang dijalankan belum sesuai dengan kebutuhan masyarakat. Karena keberhasilan suatu organisasi jika diukur dari tingkat responsivitas maka program-program pelayanan yang dijalankan harus sejalan dengan kebutuhan dan aspirasi masyarakat sehingga pandangan masyarakat terhadap pelayanan yang diberikan mendapat respon yang baik serta masyarakat merasa puas.

\section{Responsibilitas}

Responsibilitas menjelaskan apakah pelaksanaan kegiatan organisasi publik itu dilakukan sesuai dengan prinsip-prinsip administrasi yang benar atau sesuai dengan kebijakan organisasi, baik yang eskplisit maupun implisit. Oleh sebab itu, responsibilitas bisa saja pada suatu ketika berbenturan dengan responsivitas (Dwiyanto:2006).

\section{Akuntabilitas}

Akuntabilitas Publik menunjuk pada seberapa besar kebijakan dan kegiatan organisasi publik tunduk pada para pejabat publik yang dipilih oleh rakyat. Asumsinya adalah bahwa para pejabat politik tersebut karena dipilih oleh rakyat, dengan sendirinya akan selalu mempresentasikan kepentingan rakyat. Dalam konteks ini, konsep dasar akuntabilitas publik dapat digunakan untuk melihat seberapa besar kebijakan dan kegiatan organisasi publik itu konsisten dengan kehendak masyarakat banyak. Kinerja organisasi publik tidak hanya bisa dilihat dari ukuran internal yang dikembangkan oleh organisasi publik atau pemerintah seperti pencapaian target. Kinerja sebaiknya harus dinilai dari ukuran eskternal, seperti nilai-nilai dan norma yang berlaku dalam masyarakat. Suatu kegiatan organisasi publik memiliki akuntabilitas yang tinggi kalau kegiatan itu dianggap benar dan sesuai dengan nilai dan norma yang berkembang dalam masyarakat (Dwiyanto:2006)

Akuntabilitas di kantor Badan Penanggulangan Bencana Daerah kota Palu sudah cukup baik karena setiap kegiatan atau program yang dijalankan senantiasa berdasarkan aturan-aturan yang berlaku dan memperhatikan norma serta nilai-nilai yang berlaku dimasyarakat sehingga dapat diterima dengan baik.

\section{PENUTUP}

\section{Kesimpulan}

Berdasarkan hasil penelitian yang dilakukan oleh penulis dapat disimpulkan bahwa, hasil penelitian menunjukan kinerja organisasi kantor Badan Penanggulangan Bencana Daerah kota Palu masih kurang baik, dilihat dari indikator produktivitas, kualitas layanan, responsivitas, responsibilitas, dan akuntabilitas. Meskipun indikator responsibilitas dan akuntabilitas mendapat respon yang cukup baik dari masyarakat akan tetapi indikator produktivitas, 
kualitas layanan, dan responsivitas masih sangat perlu mendapat perhatian lebih dari kantor Badan Penanggulangan Bencana Daerah kota Palu.

Hal ini disebabkan oleh beberapa faktor diantaranya kurangnya dana, sarana dan prasarana yang kurang mendukung, keterbatasan sumber daya manusia dalam segi jumlah maupun pengetahuan, maupun masih adanya program yang tidak sesuai dengan harapan dan aspirasi masyarakat. Sehingga secara langsung mempengaruhi kinerja organisasi di kantor Badan Penanggulangan Bencana Daerah kota Palu. Oleh sebab itu, kantor Badan Penanggulangan Bencana Daerah kota Palu perlu memperhatikan lagi kinerja organisasinya agar mampu mewujudkan harapan dari masyarakat.

\section{Saran}

Berdasarkan hasil kajian yang dilakukan dan temuan dalam penelitian ini, makan dalam rangka peningkatan Kinerja Organisasi pada Kantor Badan Penanggulangan Bencana Daerah Kota Palu dengan ini disaran hal-hal sebagai berikut :

1. Kantor Badan Penanggulangan Bencana Daerah kota Palu diharapkan perlu meningkatkan lagi kinerjanya terutama terkait produktivitas, kualitas layanan, serta responsivitas. Dimana ketiga indikator ini merupakan hal yang sangat penting, dalam hal meningkatkan kualitas pelayanan di Kantor Badan Penaggulangan Bencana Daerah kota Palu, karena hal ini menyangkut kepentingan orang banya. Seharusnya BPBD kota Palu bisa lebih meningkatkan lagi kegiatan pemberian sosialisasi penanggulangan bencana kepada masyarakat agar terciptanya masyarakat tanggap bencana, serta pemenuhan sarana dan prasarana penanggulangan bencana agar kualitas pelayanan yang diberikan bisa lebih baik.

2. Selain itu perlu menjadi perhatian pemerintah terkait dari pemenuhan kebutuhan dana serta sarana dan prasarana kantor, kualitas layanan,dan lebih menekankan pada aspek Sumber
Daya Manusia yang berkualitas agar kualitas kantor ini bisa menjadi lebih baik lagi.

\section{DAFTAR PUSTAKA}

\section{Jurnal}

Daswati, D., Samad, M. A., \& Wekke, I. S. (2019). Collaborative Governance Dalam Pengelolaan Integrated Community Shelter Pasca Bencana Di Kota Palu Collaborative Governance in the management of Integrated Community Shelters post disaster ( ICS ) in the City of Palu.

\section{Buku}

Dwiyanto, Agus, dkk. 2006. Reformasi Birokrasi Publik di Indonesia. Yogyakarta : Gadjah Mada University Press

Keban, Yeramis T.2006. "Enam Strategi Administrasi Publik: Konsep Teori dan Isu. Yogyakarta: PT.Gava Media Yogyakarta.

Moeheriono.2014.Pengukuran Kinerja Berbasis Kompetensi”.Jakarta:PT. Raja Grafindo.

Nawawi, Ismail. 2013. Budaya Organisasi Kepemimpinan dan Kinerja. Jakarta: Prenamedia.

Siguharto, Nurjanah (dkk). 2012.Manajemen Bencana.

Bandung :Alfabeta.

Sudarmanto. 2014. Kinerja dan Pengembangan Kompetensi SDM. Yokyakarta: PustakaPelajar

Wibowo. 2009. Manajemen Kinerja. Jakarta: Raja GrafindoPersada.

\section{Dokumen}

Undang-Undang Nomor 24 Tahun 2007 Tentang Penanggulangan Bencana.

Peraturan Daerah Kota Palu Nomor 2 Tahun 2009Tentang Organisasi dan Tata Kerja Badan Peanggulangan Bencana Daerah.

Peraturan Daerah Kota Palu Nomor 5 Tahun 2011 Tentang Penyelenggaraan 
Penanggulangan Bencana.

\section{Sumber Lain}

Pedoman Penyusunan Proposal Penelitian

dan Skripsi Jurusan Ilmu

Administrasi.Fisip-Untad 2012. 